\title{
Perbedaan hasil belajar antara penerapan model cooperative learning tipe Think Pair Share (TPS) dan Problem Based Learning (PBL) pada mata pelajaran dasar pemrograman siswa kelas X di SMK Negeri 2 Madiun
}

\author{
Wahyu Sakti G. Irianto ${ }^{1}$, Syaad Patmanthara ${ }^{2}$, Evania Kurniawati ${ }^{3}$ \\ 1. Universitas Negeri Malang, Indonesia | iriantowsg@yahoo.com \\ 2. Universitas Negeri Malang, Indonesia | syaad.ft@um.ac.id \\ 3. Universitas Negeri Malang, Indonesia | evan.nhea@gmail.com
}

\begin{abstract}
Abstrak
Tujuan dari penelitian ini adalah membuktikan signifikansi perbedaan hasil belajar dari penerepan model pembelajaran TPS pada mata pelajaran. Rancangan penelitian ini menggunakan kuantitatif komparatif dengan metode eksperimen semu (quasi eksperimental). Populasi dan sampel penelitian ini adalah seluruh siswa kelas X MM 1 sebagai kelas eksperimen dan X MM 2 sebagai kelas kontrol di SMKN 2 Madiun.Variabel penelitian terdiri dari variabel bebas yaitu model pembelajaran dan variabel terikat adalah hasil belajar. Dari hasil penelitian dan analisa menggunakan uji-t dan uji Mann-Whitney didapat hasil bahwa model pembelajaran TPS dan PBL bisa meningkatkan hasil belajar, dan terdapat perbedaan yang signifikan.
\end{abstract}

Kata Kunci

Teknik Informatika, Think Pair Share (TPS), Problem Based Learning (PBL)

TEKNO Vol. 27 No 1, p30-36 | Jurusan Teknik Elektro, Universitas Negeri Malang, Indonesia | Maret 2017

W.S.G. Irianto, S. Patmanthara, E. Kurniawati | Perbedaan hasil belajar antara penerapan model cooperative learning tipe... 


\section{TEKNO Jurnal Teknologi, Elektro, dan Kejuruan}

http://journal2.um.ac.id/index.php/tekno | ISSN 1693-8739

\section{Pendahuluan}

Kualitas suatu bangsa ditentukan oleh faktor pendidikan. Pendidikan merupakan salah satu usaha masyarakat untuk memajukan peradaban dan mengembangkan ilmu pengetahuan. Dalam era globalisasi pendidikan memiliki peranan yang sangat penting (Amir, 2009). Guru sebagai pengajar dan pendidik adalah ujung tombak dari pendidikan sehingga dalam menghadapi tantangan globalisasi dituntut untuk meningkatkan profesionalitasnya. Salah satu langkah yang harus dilakukan seorang pendidik untuk meningkatkan profesionalitas pendidikan yaitu memperbaiki kualitas pembelajarannya. Kualitas pem-belajaran yang baik, mampu membangun suatu mentalitas dan perilaku peserta didik supaya tangguh dalam menghadapi tantangan dinamika kehidupan global.

Kegiatan yang paling pokok dalam keseluruhan proses pendidikan di sekolah adalah proses belajar mengajar. Berdasarkan hasil penelitian terhadap rendahnya hasil belajar peserta didik, hal tersebut disebabkan proses pembelajaran yang didominasi oleh pembelajaran tradisional. Pada pembelajaran ini suasana kelas cenderung teacher-centered sehingga siswa menjadi pasif (Trianto, 2010).

Pada Kurikulum 2013, mata pelajaran Dasar Pemrograman merupakan mata pelajaran yang seharusnya siswa mampu menguasai karena merupakan dasar bagi paket keahlian Informatika. Namun pada prakteknya, sebagian besar siswa mengalami kesulitan. Karena mata pelajaran Dasar Pemrograman merupakan salah satu mata pelajaran yang membutuhkan logika dan keterampilan praktikum. Logika dapat diasah melalui berbagai masalah dengan solusi yang melatih kemampuan siswa.

Setelah melakukan observasi di salah satu SMK di Kota Madiun yaitu SMK N 2 Madiun didapat hasil sebagai berikut (1) Hasil UTS mata pelajaran "Dasar Pemrograman" oleh siswa kelas $\mathrm{X}$ jurusan Multimedia memiliki nilai rata-rata kurang memuaskan (kurang dari KKM=75). Hal tersebut dapat diasumsikan bahwa hasil belajar siswa kurang memuaskan. (2) Guru mata pelajaran Dasar Pemrograman cenderung menggunakan model konvensional yang masih menekankan pada aspek kognitif sehingga siswa menjadi kurang aktif pada proses pembelajaran. (3) Model pembelajaran yang digunakan oleh guru yaitu metode ceramah membuat siswa cenderung pasif yang berakibat pada siswa yang kurang memahami materi Dasar Pemrograman. Hal ini terlihat dari kurang aktifnya siswa saat berdiskusi dan belum adanya pemerataan kesempatan kepada siswa untuk ikut berkontribusi pada saat pembelajaran berlangsung.

Berdasarkan permasalahan di atas, model pembelajaran yang telah digunakan pada mata pelajaran Dasar Pemrograman harus lebih banyak logika dan praktikum.

Dari permasalahan tersebut maka variasi model pembelajaran yang sesuai untuk diterapkan yaitu model pembelajaran TPS dan PBL. Model Cooperative Learning tipe Think Pair Share (TPS) dan model Problem Based Learning (PBL) adalah model pembelajaran yang berbasis pada pemecahan masalah. Pemecahan masalah berkaitan erat dengan mata pelajaran Dasar Pemrograman (Arikunto, 2010).

TEKNO Vol. 27 No 1, p30-36 | Jurusan Teknik Elektro, Universitas Negeri Malang, Indonesia | Maret 2017

W.S.G. Irianto, S. Patmanthara, E. Kurniawati | Perbedaan hasil belajar antara penerapan model cooperative learning tipe... 


\section{TEKNO Jurnal Teknologi, Elektro, dan Kejuruan}

http://journal2.um.ac.id/index.php/tekno | ISSN 1693-8739

Beberapa penelitian menye-butkan bahwa keduanya dapat meningkatkan hasil belajar siswa. Salah satunya yaitu hasil penelitian yang berjudul "Perbandingan Model Kooperatif Think Pair Share dengan Problem Based Learning pada Peningkatan Hasil dan Aktivitas Belajar Pembelajaran Fisiologi Tumbuhan" menyatakan bahwa ada perbedaan hasil belajar model PBL dan model TPS. Lebih jauh berdasarkan hasil nilai yang diperoleh menyatakan bahwa hasil belajar model TPS lebih tinggi dibandingakn dengan hasil belajar model PBL. Karena secara umum model pembelajaran kooperatif diarahkan oleh dosen (Yennita, 2012)

Dengan menerapkan model pem-belajaran tersebut, maka kegiatan pembelajaran tersebut bisa meningkat-kan kualitas pembelajaran. Berdasarkan uraian diatas penulis terdorong untuk melakukan penelitian yang berbentuk eksperimen dengan membandingkan model pembelajaran TPS dan PBL di SMK N 2 Madiun. Penelitian ini berjudul "Perbedaan Hasil Belajar antara Penerapan Model Cooperative Learning Tipe Think Pair Share (TPS) dan Problem Based Learning (PBL) pada Mata Pelajaran Dasar Pemrograman Kelas X di SMK Negeri 2 Madiun.

\section{Metode}

Penelitian ini menggunakan quasy experimental design yang bertujuan untuk mengetahui perbedaan hasil belajar siswa antara menggunakan model pembelajaran TPS dengan PBL. Rancangan ini menggunakan pretest untuk mengetahui kemampuan awal siswa dan posttest untuk mengetahui hasil belajar siswa setelah diberi perlakuan kedua model pembelajaran.

Tabel 1. Rancangan Eksperimen

\begin{tabular}{llll}
\hline Kelompok & Pre-test & Perlakuan & Post-test \\
\hline Eksperimen & O1 & X1 & O2 \\
Kontrol & O3 & X2 & O4 \\
\hline
\end{tabular}

Variabel penelitiaan ini adalah pembelajaran PBL dan TPS sebagai variabel bebas dan variabel terikatnya adalah hasil belajar. Populasi penelitiannya yaitu siswa kelas X MM di SMK N 2 Madiun Tahun Pelajaran 2016/2017. Sampel penelitian ini adalah kelas X MM 1 sebagai kelas eksperimen dan kelas X MM 2 sebagai kelas kontrol.

Instrumen penelitian yang digunakan yaitu instrumen perlakuan yang meliputi: (1) RPP, (2) materi pembelajarn, (3) media pembelajaran, dan (4) lembar keterlaksanaan model pembelajaran. Sedangkan instrumen pengukuran meliputi: (1) soal pretest digunakan untuk mengetahui kemampuan awal siswa dan posttest untuk mengetahui nilai akhir siswa setelah diberi perlakuan dengan bentuk soal tes sejumlah 30 soal yang sudah divalidasi, (2) lembar observasi untuk penilaian afektif dan psikomotor.

Uji instrumen meliputi: (1) uji validitas isi untuk mengukur kevalidan soal yang dibuat terhadap ranah materi, kontruksi dan ranah bahasa yang dipakai, (2) validasi butir soal, (3) uji reliabilitas tes, (4) uji tingkat kesukaran butir soal, dan (5) uji daya beda butir soal. 


\section{TEKNO Jumal Teknologi, Ekekro, dan Kejuruan}

http://journal2.um.ac.id/index.php/tekno | ISSN 1693-8739

Teknik analisis data berupa uji prasyarat analisis yang meliputi: (1) uji normalitas yang bertujuan untuk mengetahui apakah data terdistribusi normal atau tidak, (2) uji homogenitas digunakan untuk mengetahui homogen atau tidaknya data yang dianalisis.

Uji hipotesis digunakan untuk mengetahui apakah terdapat perbedaan hasil belajar dari ranah kognitif, afektif, psikomotor yang diuji menggunakan analisis uji-t dan uji Mann-Whitney dengan bantuan SPSS 20.

\section{Hasil}

Hasil validasi isi soal pretest yang divalidasi oleh guru mata pelajaran Aulia Rahmah, S.Pd. dan Rindang Widya Prabowo, S.Kom. yang dapat dilihat pada Tabel 2 sebagai berikut:

Tabel 2. Hasil Validasi Soal Pretest dan Posttest

\begin{tabular}{ccc}
\hline Validator & Persentase Validasi & Kriteria \\
\hline Aulia Rahmah & $90 \%$ & Sangat tinggi \\
Rindang Widya P & $94,4 \%$ & Sangat tinggi \\
\hline
\end{tabular}

Hasil validasi butir soal dapat dilihat pada Tabel 3 sebagai berikut:

Tabel 3. Hasil Validasi Butir Soal

\begin{tabular}{clcc}
\hline No & \multicolumn{1}{c}{ Butir Soal } & Jumlah & Keterangan \\
\hline 1 & $2,3,6,7,8,10,11,12,14,15,17,18,19,20,21,25,27,28$, & 30 & Valid \\
& $29,30,31,32,33,34,35,36,37,38,39,40$ & & \\
2 & $1,4,5,9,13,16,22,23,24,26$ & 10 & Tidak valid \\
\hline
\end{tabular}

Hasil uji reliabilitas soal dapat dilihat pada Tabel 4 sebagai berikut:

Tabel 4. Hasil Uji Reliabilitas

\begin{tabular}{cc}
\hline Cronbach's Alpha & Jumlah soal \\
\hline 0,871 & 40 \\
\hline
\end{tabular}

Hasil uji kesukaran butir soal dapat dilihat pada Tabel 5 sebagai berikut:

\begin{tabular}{|c|c|c|c|}
\hline Kriteria & Nomor Soal & Jumlah & Persentase \\
\hline Mudah & $1,15,17,28,37,39$ & 6 & $15 \%$ \\
\hline Sedang & $\begin{array}{l}2,3,4,5,6,7,8,9,10,11,12,13,14,1618,19,20,2 \\
1,24,25,26,27,29,30,31,32,33,34,35,38,40\end{array}$ & 31 & $77,5 \%$ \\
\hline Sukar & 22,23,36 & 3 & $7,5 \%$ \\
\hline
\end{tabular}

Hasil uji daya beda dapat dilihat pada Tabel 6 sebagai berikut: 


\section{TEKNO Jumal Teknologi, Eektro, dan Keivuruan}

http://journal2.um.ac.id/index.php/tekno | ISSN 1693-8739

Tabel 6. Hasil Perhitungan Daya Beda Soal

\begin{tabular}{llll}
\hline Kriteria Soal & Nomor Soal & Jumlah & Persentase \\
\hline Jelek & $1,4,5,9,13,16,20,22,24,26$ & 10 & $25 \%$ \\
Cukup & $3,11,18,23,28,29,31,34,36,38,39,40$ & 13 & $32,5 \%$ \\
\hline Kriteria Soal & Nomor Soal & Jumlah & Persentase \\
\hline Baik & $2,6,7,8,12,14,15,17,19,21,27,30,32,33,35,37$ & 16 & $40 \%$ \\
Baik sekali & 10 & 1 & $2,5 \%$ \\
\hline
\end{tabular}

\section{Pembahasan}

Dari hasil penelitian diperoleh nilai prettest dan postest seperti Gambar 1 berikut:

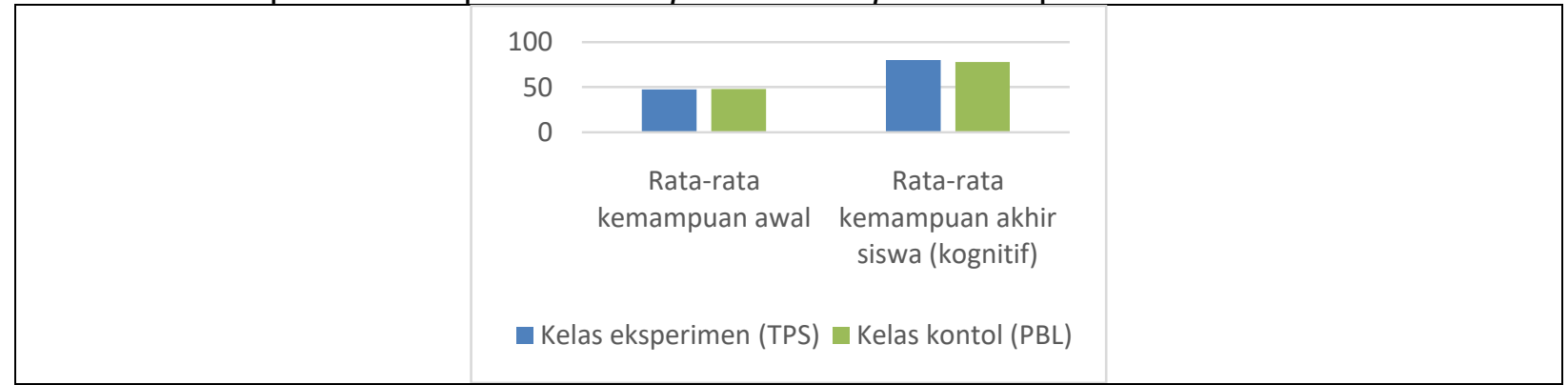

Gambar 1. Grafik Nilai Kognitif Awal dan Akhir

Berdasarkan Gambar 1 dapat diketahui bahwa terjadi peningkatan hasil belajar ranah kognitif kelas eksperimen dan kelas kontrol yang sudah diberi perlakuan.

Berdasarkan hasil uji hipotesis yang telah dilakukan dapat diketahui bahwa $t_{\text {hitung }}=0,821$ dan $t_{\text {tabel }}=2,005$ Sehingga dapat disimpulkan bahwa ada perbedaan yang signifikan penggunaan model pembelajaran cooperative learning tipe think pair share (TPS) dan penggunaan model pembelajaran Problem Based Learning PBL terhadap hasil belajar siswa. Hal ini semakin diperkuat dengan hasil belajar pada mata pelajaran dasar pemrograman yang diperoleh pada kelas kontrol yang menggunakan model PBL dengan jumlah sebanyak 30 siswa memiliki nilai rata-rata 77,83 dan kelas eksperimen yang menggunakan model TPS dengan jumlah sebanyak 28 siswa memiliki nilai rata-rata lebih tinggi 79,96.

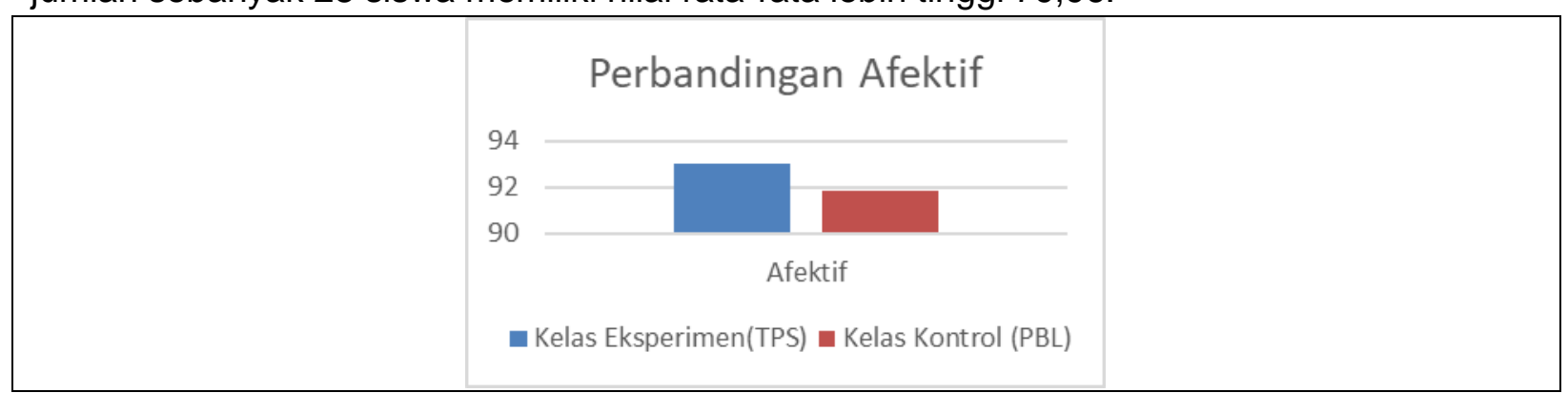

Gambar 2. Grafik Nilai Afektif kelas eksperimen dan kelas kontrol

Rata-rata hasil belajar ranah afektif siswa kelas eksperimen 93,03 dan 91,83 untuk ratarata kelas kontrol. Artinya terapat perbedaan hasil belajar (afektif) antara penerapan model TPS

TEKNO Vol. 27 No 1, p30-36 | Jurusan Teknik Elektro, Universitas Negeri Malang, Indonesia | Maret 2017

W.S.G. Irianto, S. Patmanthara, E. Kurniawati | Perbedaan hasil belajar antara penerapan model cooperative learning tipe... 


\section{TEKNO Jurnal Teknologi, Elektro, dan Kejuruan}

http://journal2.um.ac.id/index.php/tekno | ISSN 1693-8739

dan PBL pada kelas eksperimen dan kelas kontrol. Hasil uji beda dengan uji-U (Mann-Whitney) diperoleh nilai signifikansi (2-tailed) yaitu yaitu $0,048(<0,05)$, sehingga $\mathbf{H a}_{2}$ diterima. Artinya, dapat disimpulkan bahwa terdapat perbedaan yang signifikan hasil belajar ranah afektif antara penerapan model TPS dan PBL.

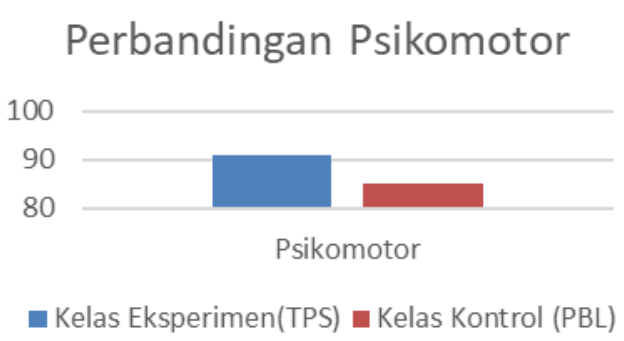

Gambar 3. Grafik nilai psikomotor kelas eksperimen dan kelas kontrol

Rata-rata hasil belajar ranah psikmotor siswa kelas eksperimen 91,42 dan 85,16 untuk rata-rata kelas kontrol. Artinya terapat perbedaan hasil belajar (afektif) antara penerapan model TPS dan PBL pada kelas eksperimen dan kelas kontrol. Hasil uji beda dengan uji-U (MannWhitney) diperoleh nilai signifikansi (2-tailed) yaitu yaitu $0,000(<0,05)$, sehingga $\mathrm{Ha}_{3}$ diterima. Artinya, dapat disimpulkan bahwa terdapat perbedaan yang signifikan hasil belajar ranah psikomotor antara penerapan model TPS dan PBL.

Berdasarkan hasil tersebut dapat ditarik sebuah kesimpulan dari penelitian ini yaitu terdapat perbedaan hasil belajar ranah kognitif, afektif, dan psikomotor yang signifikan antara penerapan model Cooperative Learning Tipe Think Pair Share (TPS) dan Model Problem Based Learning (PBL) pada mata pelajaran Dasar Pemrograman kelas X di SMK Negeri 2 Madiun.

Hal ini sesuai dengan pendapat Ruseeffendi (1991:7) (dalam Susanto, 2013) yaitu faktorfaktor yang mempengaruhi hasil belajar yaitu kecerdasan, kesiapan anak, bakat anak, kemauan belajar, minat anak, model penyajian materi, pribadi dan sikap guru, suasana belajar, kompetensi guru, dan kondisi masyarakat.

Pada pembelajaran model TPS nilai siswa dapat lebih tinggi karena siswa dikelompokkan dan diarahkan untuk saling bertukar pikiran secara aktif. Siswa berkelompok kemudian menyelesaikan suatu permasalahan, Lalu berkelompok kembali begitu seterusnya.

Sedangkan pada PBL, siswa diberikan permasalahan $\rightarrow$ kemudian siswa berkelompok untuk mencari pemecahan masalah $\rightarrow$ Lalu siswa menyelesaikan permasalahan itu secara mandiri.

\section{Kesimpulan}

Berdasarkan hasil penelitian dan analisis data yang dilakukan, maka dapat disimpulkan bahwa:

TEKNO Vol. 27 No 1, p30-36 | Jurusan Teknik Elektro, Universitas Negeri Malang, Indonesia | Maret 2017

W.S.G. Irianto, S. Patmanthara, E. Kurniawati | Perbedaan hasil belajar antara penerapan model cooperative learning tipe... 


\section{TEKNO Jurnal Teknologi, Elektro, dan Kejuruan}

http://journal2.um.ac.id/index.php/tekno | ISSN 1693-8739

1. Nilai rata-rata hasil belajar dengan penerapan Cooperative Learning Tipe Think Pair Share (TPS) yaitu 79,96 untuk nilai hasil belajar ranah kognitif, 93,03 untuk nilai hasil belajar ranah afektif, dan 91,42 untuk nilai hasil belajar ranah psikomotor.

2. Nilai rata-rata hasil belajar dengan penerapan Problem Based Learning (PBL) yaitu 77,83 untuk nilai hasil belajar ranah kognitif, 91,83 untuk nilai hasil belajar ranah afektif, dan 85,16 untuk nilai hasil belajar ranah psikomotor.

3. Hasil uji beda hasil belajar ranah kognitif (pengetahuan) diperoleh terdapat perbedaan yang signifikan antara rata-rata hasil belajar ranah pengetahuan menggunakan penerapan model pembelajaran TPS (Think Pair Share) dengan model pembelajaran PBL (Problem Based Learning) di kelas $X$ Jurusan Multimedia di SMKN 2 Madiun. Siswa dengan penerapan model TPS memiliki rata-rata nilai kognitif lebih tinggi daripada model PBL.

4. Hasil uji beda hasil belajar ranah afektif (sikap) diperoleh terdapat perbedaan yang signifikan antara rata-rata hasil belajar ranah sikap menggunakan penerapan model pembelajaran TPS (Think Pair Share) dengan model pembelajaran PBL (Problem Based Learning) di kelas $X$ Jurusan Multimedia di SMKN 2 Madiun. Siswa dengan penerapan model TPS memiliki rata-rata nilai afektif lebih tinggi daripada model PBL.

5. Hasil uji beda hasil belajar ranah psikomotor (keterampilan) diperoleh terdapat perbedaan yang signifikan antara rata-rata hasil belajar ranah keterampilan menggunakan penerapan model pembelajaran TPS (Think Pair Share) dengan model pembelajaran PBL (Problem Based Learning) di kelas X Jurusan Multimedia di SMKN 2 Madiun. Siswa dengan penerapan model TPS memiliki rata-rata nilai psikomotor lebih tinggi daripada model PBL.

\section{Saran}

Model pembelajaran TPS dan PBL dapat digunakan sebagai alternatif cara mengajar guru produktif di SMKN 2 Malang yang terbukti bisa mening-katkan hasil belajar siswa

\section{Daftar Rujukan}

Amir, Taufik. 2009. Inovasi Pendidikan Melalui Problem Based Learning. Jakarta: Kencana.

Arikunto. 2010. Manajemen Penelitian. Jakarta. Rineka Cipta.

Susanto, Ahmad. 2013. Teori Belajar dan Pembelajaran. Jakarta: Kencana.

Trianto. 2010. Mendesain Model Pembelajaran Inovatif-Progresif: Konsep, Landasan, dan Implementasinya pada Kurikulum Tingkat Satuan Pendidikan. Jakarta: Kencana Prenada Media Group.

Yennita. 2012. Perbandingan Model Kooperatif Think Pair Share dengan Problem Based Learning pada Peningkatan Hasil dan Aktivitas Belajar Pembelajaran Fisiologi Tumbuhan. Bengkulu: Jurnal Exacta 